\title{
Comparison of Antioxidant Effects of Kolaviron and Vitamin C Interventions on Testicular Structures Following Nevirapine Administration in Sprague-Dawley Rats
}

\author{
Comparación de los Efectos Antioxidantes en la Intervención con Kolaviron y Vitamina C sobre \\ las Estructuras Testiculares Después de la Administración de Nevirapina en Ratas Sprague-Dawley
}

\author{
S. A. Ajayi"; O. O. Azu*; A. Chuturgoon ${ }^{* *}$; A. Phulukdaree**; O. A. Komolafe* \& D. A. Ofusori***
}

AJAYI, S. A.; AZU, O. O.; CHUTURGOON, A.; PHULUKDAREE, A.; KOMOLAFE, O. A. \& OFUSORI, D. A. Comparison of antioxidant effects of Kolaviron and Vitamin c interventions on testicular structures following Nevirapine administration in SpragueDawley rats. Int. J. Morphol., 34(1):102-109, 2016.

SUMMARY: Testicular toxicity has been implicated in highly active anti-retroviral therapy (HAART) treatment. Hence there is need to identify an effective antioxidant product that can alleviate testicular necrosis due to HAART administration. Forty eight adult male Sprague-Dawley rats were used in this study. The animals were divided into eight (8) groups: A-H ( $\mathrm{n}=6$ ). Group A animals received normal saline as the control; Group B was given Nevirapine (Nv); Group C was given Kolaviron (Kv); Group D was given vitamin C; Group E was given Nv and Kv; Group F was given Nv and Vitamin C; Group G was given Nv for $56 \mathrm{~d}$ and $\mathrm{Kv}$ for $28 \mathrm{~d}$ serving as a withdrawal group; Group H was given corn oil. Nv, Kv and Vit. C were given at 1.54, 200 and 250 (mg.kg)/bw respectively while all administrations were through oral gavage. The body weights were taken every other day. Thereafter, they were anaesthetized with halothane. The testes were excised, weighed, fixed in Bouin's fluid and stained with H\&E while the epididymes removed for semen fluid analyses. The results showed a significant $(\mathrm{P}<0.05)$ decrease in sperm motility in group $\mathrm{E}$ (Nevirapine + kolaviron) when compared with group F (Nevirapine + Vitamin C) while Sperm count was not significantly different $(\mathrm{P}>0.05)$ across the groups. The testicular histoarchitectural studies revealed indistinct spermatogonia, necrotic interstititial endocrine cells in the altered interstitial space, fragmented spermatids, atrophy of mature spermatocytes, degenerated germ cells, obliterated seminiferous tubules lumen, undifferentiated spermatogonia and cellular debris in the somniferous tubules lumen of nevirapine administered group but normal across the other groups. In the testis, there were no significant reduction in SOD, Catalase and GPx activities but a significant decrease in GST activity $(\mathrm{P}<0.001)$ when group $\mathrm{E}$ was compared with group $\mathrm{F}$. In conclusion, vitamin $\mathrm{C}$ presents a better remediation in nevirapine induced spermiotoxicity compared to kolaviron in Sprague-Dawley rats.

KEY WORDS: Nevirapine; Kolaviron; Testicular toxicity; Sperm count; Antioxidant enzymes.

\section{INTRODUCTION}

Currently, HIV/AIDS is the fourth leading cause of death globally and a leading cause of death in Africa (UNAIDS, 2009) with estimated 34 and 5,38 million people living with the virus worldwide and in South Africa respectively (Statistics South Africa, 2011). The sexual transmission of HIV has been admitted by UNAIDS to be the most complex mode of transmission of the virus and it has remained the most difficult mode to control (UNAIDS). In 2008, the World Health Organization estimated that more than 2 million people living with HIV/AIDS were receiving treatment in Low and Middle-Income Countries, representing only $28 \%$ of the estimated 7.1 million people in need (WHO, 2008). Against this backdrop, HIV/AIDS continues to ravage the health and economic parameters of both developed and developing countries with attendant negative impact on human welfare and productivity.

The standard care for the treatment of HIV-1 infection involves combination of antiretroviral drugs (the so-called highly active anti-retroviral therapy HAART) which includes the use of Nucleoside Reverse Transcriptase Inhibitors (NRTIs) with either Non-Nucleoside Reverse Transcriptase

\footnotetext{
* Discipline of Clinical Anatomy, Nelson R. Mandela School of Medicine, University of KwaZulu-Natal, Durban, South Africa.

** Department of Medical Biochemistry, School of Laboratory Medicine and Medical Sciences, University of KwaZulu-Natal, Durban, South Africa.

**** Optics and Imagining Centre, School of Laboratory Medicine and Medical Sciences, University of KwaZulu-Natal, Durban, South Africa.
} 
Inhibitors (NNRTIs) or Protease Inhibitors (PIs). NNRTIs have been shown to be superior alternatives to PIs owing to the latters' severe metabolic perturbations in patients (Saag et al., 2002). However, despite the dramatic improvement in the survival of HIV infected individuals (Kayode et al., 2011), HAART comes with its attendant undesirable toxicities that have mitigated its use and compliance by patients (Umar et al., 2008). Nevirapine, a NNRTI, has been used as a first-line antiretroviral treatment regime with positive success (Podzamcer \& Fumero, 2001) but unwanted adverse hepatotoxicity (Kontorinis \& Dieterich, 2003) is repleted. This is in addition to reported spermiotoxic effects related to reduction in sperm motility and viability with necrosis of spermatids in experimental (Adaramoye et al., 2005) and cross-sectional study of human semen samples (Lambert-Niclot et al., 2011).

The use of Vitamins (C and E) as antioxidant supplement in ART has been practiced both in experimental and clinical conditions because they act as scavengers for generated free radicals in living cells. However, ineffectiveness in single dose of these easily accessed andcheap antioxidants has shifted the attention of researchers towards the use of combined antioxidants which also come with its own disadvantages. Hence, the recent interest is in indigenous knowledge system (herbal products).

Kolaviron, a predominant active component of Garcinia kola with natural antioxidant (biflavonoid) has been reported to elicit strong antioxidant activity both in vivo and in vitro. Based on Kolaviron intrinsic antioxidant and antiapoptotic properties, it is commonly implored as a potential candidate useful in combating reproductive dysfunction and endocrine pathology induced by toxic compounds (Farombi et al., 2007). The aim of this study is to comparatively elucidate the efficacy of Kolaviron and vitamin $\mathrm{C}$ in the treatment of Nevirapine induced testicular toxicity in Sprague - Dawley rats.

\section{MATERIAL AND METHOD}

Animals. Forty eight (48) adult male Sprague-Dawley rats (weighing 200-250 g) were used for this experiment. The animals were fed with standard rat pellet at animal holdings, Biomedical Research Unit (BRU), Westville campus, University of KwaZulu-Natal, Durban, South Africa and water given ad libitum. The animals were handled in accordance with guidelines for animal research as detailed in the NIH Guidelines for the Care and Use of Laboratory Animals (NIH, 1985) with the ethical approval from the University of KwaZulu-Natal Ethics Research Committee.
Plant material. Garcinia kola seeds were purchased from markets in Eda-Oniyo Ekiti, Ekiti State, Nigeria. The seeds were taken to the Herbarium unit of the Department of Botany, Obafemi Awolowo University, Ile-Ife, Nigeria for identification: Voucher number: NHI 16745 and sample deposited at herbarium for future reference.

Extraction of Kolaviron. Extraction of Kolaviron was achieved by the procedure previously described by Iwu (1985) and modified by Braide (1991). The outer cover of Garcinia kola seeds were peeled, sliced and air-dried in the laboratory $\left(25-28{ }^{\circ} \mathrm{C}\right)$ and grounded into powdered form. The powdered seeds were extracted with n-hexane, in a soxhlet extractor for $24 \mathrm{~h}$. The defatted, dried marc was repacked and then extracted with methanol in a soxhlet extractor. The extract was concentrated and diluted to twice its volume in distilled water and extracted with ethyl acetate (6x300 mL). The concentrated ethyl acetate yielded Kolaviron, a golden yellow solid.

Drugs procurement. Nevirapine (Aspen) and Vitamin C (Lascorbic acid) were procured from Pharmacare Ltd. (Port Elizabeth, South Africa) and were of analytical grade with expiry date still in order.

Treatment. The animals were divided into eight (8) groups: A, B, C, D, E, F, G and H ( $n=6)$. Group A animals received normal saline as the control; Group B were given $\mathrm{Nv}$ at concentration of $1.54(\mathrm{mg} \cdot \mathrm{kg}) / \mathrm{bw}$; Group C were given $\mathrm{Kv}$ at concentration of $200(\mathrm{mg} \cdot \mathrm{kg}) / \mathrm{bw}$; Group D were given vitamin $\mathrm{C}$ at concentration of $250(\mathrm{mg} \cdot \mathrm{kg}) / \mathrm{bw}$; Group E were given $\mathrm{Nv}$ and $\mathrm{Kv}$ at concentrations of $1.54(\mathrm{mg} \cdot \mathrm{kg}) / \mathrm{bw}$ and $200(\mathrm{mg} \cdot \mathrm{kg}) / \mathrm{bw}$ once respectively; Group F were given $\mathrm{Nv}$ and Vitamin C at concentrations of $1.54(\mathrm{mg} \cdot \mathrm{kg}) / \mathrm{bw}$ and $250(\mathrm{mg} \cdot \mathrm{kg}) / \mathrm{bw}$; Group $\mathrm{G}$ were given Nv at concentrations of $1.54(\mathrm{mg} \cdot \mathrm{kg}) / \mathrm{bw}$ and $\mathrm{Kv}$ for $28 \mathrm{~d}$ serving as a withdrawal group; Group H were given corn oil. All administrations were by oral gavages. The experiment lasted for $56 \mathrm{~d}$ which is the duration for the completion of a spermatogenetic wave.

Body weights were taken every other day during administration of drugs and the final weight was used for the estimation of Relative Testis Weight which was calculated as: Weight of the testis/ Final body weight of the animal $\mathrm{x}$ 100.

Semen collection and semen fluid analysis. The scrotum were excised; testis removed along with the epididymis and weighed using Mettler Toledo analytical balance (Microsep (pty) Ltd., Switzerland). The epididymides were thereafter removed from the testis for semen fluid analysis. Semen was gotten from the caudal epididymis onto a petri-dish that contains $5 \mathrm{~mL}$ of normal saline. Drop of the semen mixed 
with normal saline was put on slide. The slide was covered with cover slip and examined under microscope. The motility of 100 spermatocytes was assessed randomly. The spermatocytes were labeled as motile, sluggish or immotile. The percentage sperms were defined as the number of motile sperms divided by the total number of counted sperms.

Sperm count. The Epididymis in the petri-dish containing $5 \mathrm{~mL}$ of normal saline was chopped into smaller pieces for expulsion of semen present in it. This was dispensed into a plain tube and vortex for few seconds to allow proper mixture. $90 \mu \mathrm{L}$ of normal saline was collected using a micropipette and dispensed in an Ependorff tube for the dilution of $10 \mu \mathrm{L}$ of already prepared sperm samples. These were stirred properly using the vortex. Five $\mu \mathrm{L}$ of the mixture and were collected using a micropipette and injected into the Automated Cell Counter special slide. Thereafter the slide was inserted into the 1450101TC20TM Automated Cell Counter (Bio-Rad Laboratory Inc. (HP27DX), United Kingdom).

Histopathological assessment. The testis were removed, weighed and fixed in Bouin's fluid. The fixed tissues were processed for Light Microscopy. The paraffin wax blocked tissues were section at 4 micron using rotary microtome. These were stained with Haematoxylin and Eosin (H\&E) and thereafter examined under light microscope. Images were scanned using slide Scanner (Leica SCN 400, Leica MicrosystemGmbh, Wetzlar, Germany). The photomicrographs of the scanned Slide were measured at reported magnifications (scale bars) using image analyser Leica (DMLB) and Leica QWIN Software.

\section{Biochemical assays}

Antioxidant activities. All animals were sacrificed, the right testis were quickly excised, rinsed in ice-cold saline to clear them of blood, weighed, snap fixed in liquid nitrogen and stored at $-81{ }^{\circ} \mathrm{C}$ until required for antioxidant enzyme activities analysis. The testis were finely minced in the PBS and homogenized (approximately $30 \% \mathrm{w} / \mathrm{v}$ ) in a Corning Potter Elvehjem homogenizer. The homogenates were centrifuged (Beckman, Indianapolis, IN, USA) at $100000 \mathrm{~g}$ for $30 \mathrm{~min}$ at $4{ }^{\circ} \mathrm{C}$. The resulting supernatants were used for Superoxide Dismutase (SOD), Catalase, Glutathione peroxidase (GPx) and Glutathione s-transferase (GST) activities.

Statistical analysis. The values were presented as mean \pm SEM. Continuous data were analyzed using Student's t-test and one way analysis of variance (ANOVA) with Duncan multiple range test using SPSS version 17, with $\mathrm{P}<0.05$ considered significant.

\section{RESULTS}

Mortality. The 48 Sprague-Dawley rats which were provided by the Biomedical research Unit were free of pathogens thereby, mortality was not recorded in any of the experimental groups during the period of the research.

Relative testis weight. The relative testis weight was significantly reduced in Kolaviron treated group (group E) when compared with Vitamin C treated group (group F) as shown in Table I.

Sperm motility and sperm count. The results showed that both Kolaviron and Vitamin $\mathrm{C}$ treatment groups increased sperm motility of Nevirapine induced testicular toxicity to near normal as shown in Table II.

The scenario was different in sperm count as nevirapine administration showed no significant different when control group was compared with nevirapine administered group (Table II).

Histopathology. The assessment of the histoarchitectural patterns of the testicular structures in control animals revealed normal layered spermatogenic series, intact interstititial endocrine cells (Leydig cells) in the interstitial spaces and sustentocytes (Sertoli cells) (Fig. 1).

Testis of animals treated with Nevirapine revealed appreciable number of undifferentiated cells which were seen at the lumen of the seminiferous tubule (Fig. 2). Some seminiferous tubules presented shed spermatocytes with so many flagella of the spermatocytes pushed side way while the heads are congested at the lumen of the seminiferous tubules. Distorted spermatocytes were evident in the lumen of many of the seminiferous tubules. Atrophied tubules and vacuolations were also noted at the interstitial spaces of these testes (Fig. 2-Bi and Bii). Nevertheless, few seminiferous tubules still presented normal histoarchitecture. Also, Testicular structures of the groups treated with Kolaviron and vitamin $\mathrm{C}$ presented normal histoarchitecture (Fig. 1).

Antioxidant enzyme. In the testes, the SOD and GST activities of nevirapine treated group were significantly reduced but Catalase and GPx activities were not significantly reduced. In all the remaining groups, the antioxidant enzyme activities were not significantly different except GST activity which increased significantly $(\mathrm{p}<0.001)$ in co-administration of Nevirapine and Vitamine C (Fig. 3). 




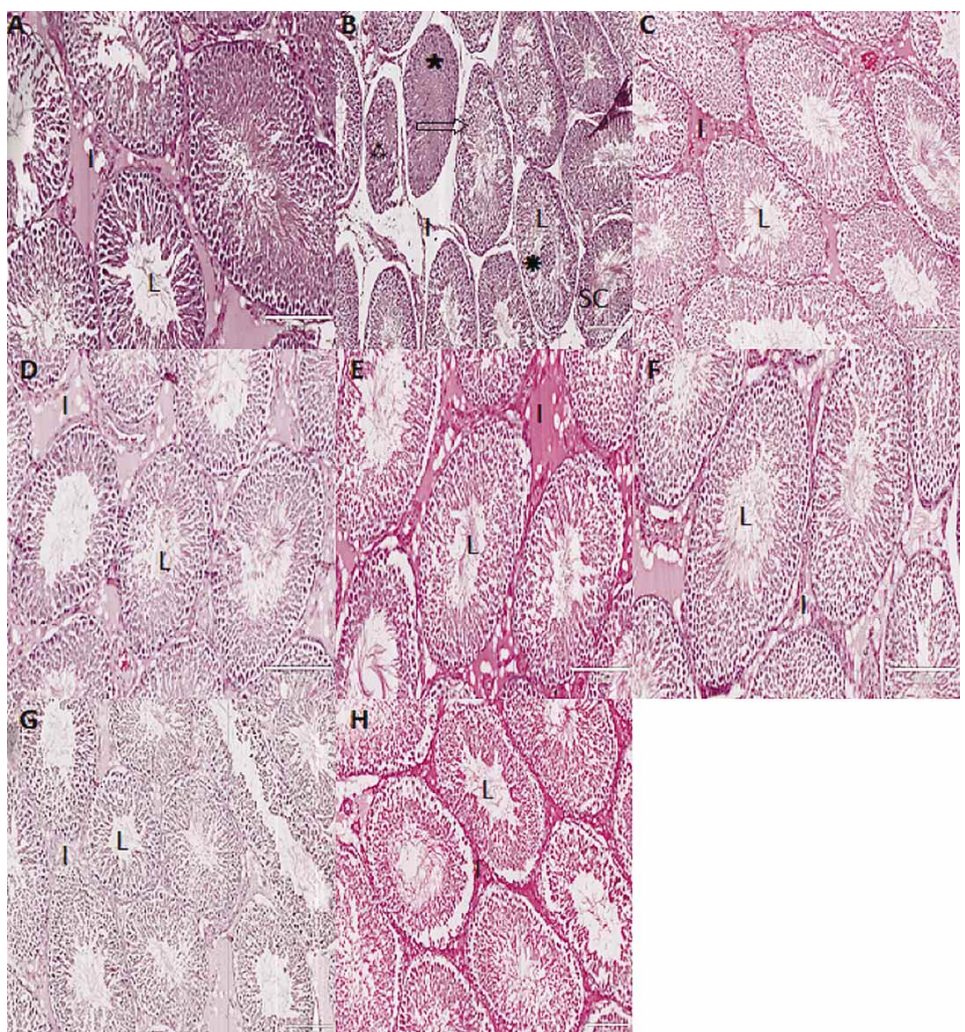

Fig.1. Photomicrographs of transverse sections of seminiferous tubules showing the spermatogenic cell (SC) at various stages of development; lumn (L) of the seminiferous tubules interstitial space (I) containing the interstititial endocrine cells in groups (A-H). Note the seminiferous tubules of group B (Nevirapine administered group) which presented depletion of seminiferous epithelium (arrow), degenerated germ cells $(* * *)$, undifferentiated spermatogonia $(*)$ and celular debris in the lumen $(*)$. Scale bar $10 \times 200$ mm. H\&E. 

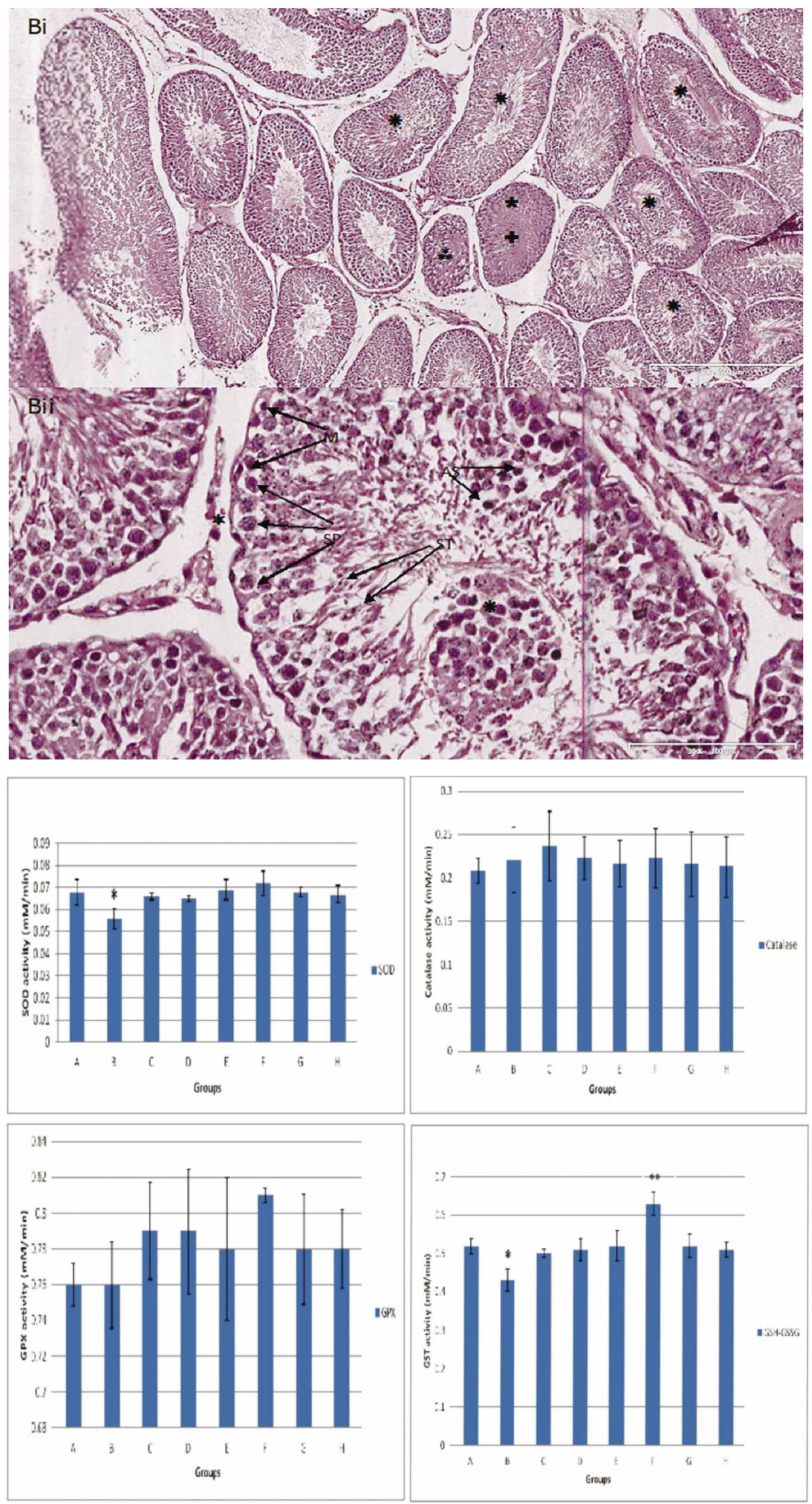

Fig. 2. Photographs of tranverse sections of seminiferous tubule of group B (Nevirapine administered group) at various magnifications showing deformed muscle cells $(\mathrm{M})$; insdistinct spermatogonia (SP); reduced number of interstititial endocrine cells in the destroyed interstitial space $(*)$. It presented fragmented seminiferous (ST), Atrophy of mature spermatocytes (AS), degenerated germ cell (***), obliterated seminiferous tubule lumen (:): undifferentiated spermatogonia $(*)$. Scale bar: $\mathrm{Bi}=5 \mathrm{x} 500 \mathrm{~mm}$; BII $=30 \mathrm{x}$ $100 \mathrm{~mm}$. H\&E.

Fig. 3 Graphical representation of total Superoxide Dismutase (SOD), Catalase, Glutathione Peroxidase (GPx) and Glutationes S-Transferase (GST) activities in the testes of Sprague-Dawley rats across the groups reported as Mean \pm SD with significant difference $(\mathrm{p}<0.001)$. 


\section{DISCUSSION}

The importance of HAART to HIV/AIDS patients cannot be over emphasized. Despite this, HAART toxicity had been implicated in organs of male reproductive system (Azu et al., 2014) and the roles of antioxidants most especially Kolaviron (flavonoid from Garcinia kola) in alleviating the menace was earlier reported (Adaramoye et al., 2013). A kin interest is placed on Kolaviron as indigenous based product as a replacement to single dose antioxidant which is believed to be ineffective and diverted the attention of researchers to the use of combined antioxidants. This study is focused on analyzing the possible use of Kolaviron as alternative antioxidants to ameliorate HAART toxicity to sperm cell parameters and micro - anatomical structures of the testis.

Relative organ weight is a standard and generally acceptable modality for measuring the level of toxicity in the particular organ of interest. The decrease in relative testis weight in co-administration of Nevirapine and Kolaviron to Sprague-Dawley rats when compared with co-administration of Nevirapine and Vitamin C was an indication of metabolic dysfunctions which may suggest a reduction in the number of sustentocytes and/or interstititial endocrine cells and disruptions in spermatogenic cells because the decrease was not significantly different with the relative testis weight of the animals administered with Nevirapine only. The reduction of relative testis weight in this study could also be an indication of alteration in androgen status (Biswas et al., 2001). Hence, Kolaviron did not significantly inhibited nevirapine spermio-toxicity. This evidently showed that antioxidant role of Kolaviron cannot be equivalently implored in solving the testicular toxicity posed on patients on HAART as compared to Vitamin C.

Toxic substances could hinder sperm motility (Manna et al., 2008). In this study, Nevirapine administration resulted into asthenozoospermia (a decrease in sperm motility) which was an indication of several abnormal sperm cells that were immotile. Both Kolaviron and Vitamin C successfully restored this Nevirapine induced asthenozoospermia without any notable variation. There were no reductions in sperm count due to treatment with Nevirapine. The sperm count which remained unaffected was based on the fact that all spermatozoa present in semen of the particular portion of the epididymis examined were counted irrespective of the status (alive or dead, normal or abnormal) of the cells.

Fragmented spermatids occurred solely in nevirapine administered group presenting no trace of deformed spermatid in Sprague-Dawley rats treated with either Kolaviron or vitamin C. Spermatids fragmentations were reported to be due to adverse and pathological circumstances (Freitas et al., 2002). Testicular structures of HAART treated animals were noted with necrotic germ cells and a decrease of almost all morphometric and stereological testicular parameters (Azu et al.). Necrosis and apoptotic death was one of the mechanisms responsible for the massive elimination of germ cells due to testicular toxicity (Amara et al., 2008; Li et al., 2010).

Indistinct and undifferentiated spermatogonia are majorly found in developing testicles and the presence of these features in nevirapine treated Sprague-Dawley rats were as a result of its toxic effects resulting in morphological alterations in sustentocytes, hence, reason for atrophy of the few spermatocytes found in the lumen of the semiferous tubules. Seminiferous tubules lumen obliteration and presence of cellular debris could be due to nevirapine crossing the blood-testis barrier by penetrating the cellular junctional complexes thereby affecting the tubular microenvironment and causing germ cell death (Meistrich et al., 1982). The effects of Kolaviron and Vitamin C in this protocol have tilted towards similarities adjudged from various parameters assessed as we have rightly reported that the integrity of interstitial spaces and seminiferous tubules were brought to normal by these antioxidants without any noticeable disparity histologically. Nevertheless, the observed interstititial endocrine cells and spermatogenic cells alterations within the testicular structures for proper evaluation of the degree of variations in the antioxidant roles Kolaviron and vitamin C treatment animals reported in this study may be better explained using ultrastructural study and stereological techniques in order to generate a 3 - dimensional approach and critical evaluation of the organelles. In this way, a more detailed quantification can be done with the aim of generating relevant approaches to the mechanisms underlying the processes.

Emphasis has been laid on the importance of mitochondrial form of SOD in controlling O2- leakage from testicular mitochondria because mRNA was reported to be higher in the testes than other organs as oppose to both GPx and Catalase (Gu \& Hecht, 1996). This actually suggests the main reason while Catalase, and GPx activities in the testes were not significantly increased in this study whereas SOD and GST activities were significant increased in Vitamin C treated animals as against Kolaviron treated ones. This evidently showed that elimination of free radicals from Nevirapine induced oxidative stress through Reactive Oxygen Species (ROS) in the testes of Sprague-Dawley rats has higher potency with Vitamin C. 


\section{CONCLUSION}

Vitamin C and Kolaviron contribute to the alleviation of Nevirapine induced spermiotoxicity and support spermatogenesis but Vitamin C proved to possess more active antioxidant properties.

\section{ACKNOWLEDGMENTS}

The present study was supported financially by University of KwaZulu-Natal, Durban, South Africa through the award of Postdoctoral Research Grant to the first author.

AJAYI， S. A.; AZU， O. O.; CHUTURGOON， A.; PHULUKDAREE, A.; KOMOLAFE, O. A. \& OFUSORI, D. A. Comparación de los efectos antioxidantes en la intervención con Kolaviron y vitamina $\mathrm{C}$ sobre las estructuras testiculares después de administración de Nevirapina en ratas Sprague-Dawley. Int. J. Morphol., 34(1):102-109, 2016.

RESUMEN: La toxicidad testicular ha sido implicada en la terapia antirretroviral altamente activa (TARAA). Por lo tanto existe la necesidad de identificar un producto antioxidante eficaz que pueda aliviar la necrosis testicular en la administración de la TARAA. Cuarenta y ocho ratas macho Sprague-Dawley adultas fueron utilizadas. Los animales se dividieron en ocho (8) grupos: $\mathrm{AH}(\mathrm{n}=6)$. Grupo A, animales recibieron solución salina normal como el control; Grupo B, recibió Nevirapina (Nv); Grupo C, recibió Kolaviron (Kv); Grupo D, recibió vitamina C; Grupo E, recibió Nv y Kv; Grupo F, recibió Nv y vitamina C; Grupo G, recibió $\mathrm{Nv}$ durante $56 \mathrm{~d}$ y $\mathrm{Kv}$ por 28 d como un grupo de retirada; Grupo H, recibió aceite de maíz. Nv, Kv y Vit. C se administraron en dosis de 1, 54, 200 y $250(\mathrm{mg} \cdot \mathrm{kg})$ de peso corporal respectivamente; todas las administraciones fueron por sonda oral. Los pesos corporales se tomaron cada dos días. A partir de ese momento los animales fueron anestesiados con halotano. Los testículos fueron extirpados, pesados y fijados en solución de Bouin y teñidos con H\&E, mientras que el epidídimo se retiró para analizar el semen. Los resultados mostraron un descenso $(p<0,05)$ en la motilidad de los espermatozoides en el grupo E (Nevirapina + Kolaviron) en comparación con el grupo F (Nevirapina + vitamina C), mientras que el recuento espermático no mostró diferencias significativas $(\mathrm{P}>0,05)$ entre los grupos. El estudio de la histoarquitectura testicular reveló espermatogonias indiferenciadas, con células intersticiales necróticas en el espacio intersticial y espermátidas fragmentadas. Además, en el grupo que recibió Nevirapina mostró espermatocitos maduros atrofiados, degeneración de células germinales, lumen de los túbulos seminíferos obliterados, espermatogonias indiferenciadas y restos celulares en el lumen de los tubulos seminíferos. En el resto de los grupos los resultados fueron normales. En el testículo hubo una reducción significativa en las actividades de la superóxido dismutasa, catalasa y glutatión peroxidasa, pero una disminución significativa en la actividad glutatión S-transferasa $(\mathrm{P}<0,001)$ al comparar los grupo E y $\mathrm{F}$.

PALABRAS CLAVE: Nevirapine; Kolaviron; Toxicidad testicular; Conteo espermático; Enzimas antioxidantes.

\section{REFERENCES}

Adaramoye, O. A.; Akanni, O. O. \& Farombi, E. O. Nevirapine induces testicular toxicity in Wistar rats: reversal effect of kolaviron (biflavonoid from Garcinia kola seeds). J. Basic Clin. Physiol. Pharmacol., 24(4):313-20, 2013.

Adaramoye, O. A.; Farombi, E. O.; Adeyemi, E. O. \& Emerole, G. O. Comparative study on the antioxidant properties of flavonoids of Garcinia kola seeds. Pak. J. Med. Sci., 21(3):331-9, 2005.

Amara, S.; Abdelmelek, H.; Garrel, C.; Guiraud, P.; Douki, T.; Ravanat, J. L.; Favier, A.; Sakly, M. \& Ben Rhouma, K. Preventive effect of zinc against cadmium-induced oxidative stress in the rat testis. J. Reprod. Dev., 54(2):129-34, 2008.

Azu, O. O.; Naidu, E. C.; Naidu, J. S.; Masia, T.; Nzemande, N. F.; Chuturgoon, A. \& Singh, S. Testicular histomorphologic and stereological alterations following short-term treatment with highly active antiretroviral drugs (HAART) in an experimental animal model. Andrology, 2(5):772-9, 2014.

Biswas, N. M.; Sen Gupta, R.; Chatopadhyay, G. R.; Choudhury, G. R. \& Sarkar, M. Effect of atenolol on cadmium-induced testicular toxicity in male rats. Reprod. Toxicol., 15(6):699704, 2001.

Braide, V. P. Pharmacological effect of chronic ingestion of Garcinia kola seeds in rats. Phytother. Res., 4(1):39-41, 1991.

Farombi, E. O.; Abarikwu, S. O.; Adedara, I. A. \& Oyeyemi, M. O. Curcumin and kolaviron ameliorate di-n-butylphthalateinduced testicular damage in rats. Basic Clin. Pharmacol. Toxicol., 100(1):43-8, 2007.

Freitas, F. E. L.; Cordeiro-Mori, F.; Sasso-Cerri, E.; Lucas, S. R. A. \& Miraglia, S. M. Alterations of spermatogenesis in etoposide-treated rats: a stereological study. Interciencia, 27(5):227-35, 2002.

Gu, W. \& Hecht, N. B. Developmental expression of glutathione peroxidase, catalase, and manganese superoxide dismutase mRNAs during spermatogenesis in the mouse. J. Androl., 17(3):256-62, 1996.

Iwu, M. M. Antihepatoxic constituents of Garcinia kola seeds. Experientia, 41(5):699-700, 1985.

Kayode, A. A. A.; Kayode, O. T.; Aroyeun, O. A. \& Stephen, M. 
AJAYI, S. A.; AZU, O. O.; CHUTURGOON, A.; PHULUKDAREE, A.; KOMOLAFE, O. A. \& OFUSORI, D. A. Comparison of antioxidant effects of Kolaviron and Vitamin c interventions on testicular structures following Nevirapine administration in Sprague-Dawley rats. Int. J. Morphol., 34(1):102-109, 2016.

C. Hematologic and hepatic enzyme alterations associated with acute administration of antiretroviral drugs. J. Pharmacol. Toxicol., 6(3):293-302, 2011.

Kontorinis, N. \& Dieterich, D. T. Toxicity of non-nucleoside analogue reverse transcriptase inhibitors. Semin. Liver Dis., 23(2):173-81, 2003.

Lambert-Niclot, S.; Poirot, C.; Tubiana, R.; Houssaini, A.; Soulié, C.; Dominguez, S.; Schubert, B.; Prades, M.; Bonmarchand, M.; Calvez, V.; Flandre, P.; Peytavin, G. \& Marcelin, A. G. Effect of antiretroviral drugs on the quality of semen. J. Med. Virol., 83(8):1391-4, 2011.

Li, J. L.; Gao, R.; Li, S.; Wang, J. T.; Tang, Z. X. \& Xu, S. W. Testicular toxicity induced by dietary cadmium in cocks and ameliorative effect by selenium. Biometals, 23(4):695-705, 2010 .

Manna, P.; Sinha, M. \& Sil, P. C. Cadmium induced testicular pathophysiology: prophylactic role of taurine. Reprod. Toxicol., 26(3-4):282-91, 2008.

Meistrich, M. L.; Finch, M.; Cunha, M. F.; Hacker, U. \& Au, W. W. Damaging effects of fourteen chemotherapeutic drugs on mouse testis cells. Cancer Res., 42(1):122-31, 1982.

National Institutes of Health (NIH). Guide for the Care and Use of Laboratory Animals. Bethesda, U. S. Dept. of Health and Human Services, Public Health Service, National Institutes of Health, 1985.

Podzamczer, D. \& Fumero, E. The role of nevirapine in the treatment of HIV-1 disease. Expert Opin. Pharmacother., 2(12):2065-78, 2001.

Saag, M. S.; Powderly, W. G.; Schambelan, M.; Benson, C. A.; Carr, A.; Currier, J. S.; Dubé, M. P.; Gerber, J. G.; Grinspoon, S. K.; Grunfeld, C.; Kotler, D. P. \& Mulligan, K. Switching antiretroviral drugs for treatment of metabolic complications in HIV-1 infection: summary of selected trials. Top. Antivir. Med., 10(1):47-51, 2002.

Statistics South Africa. Mid-Year Population Estimates. Statistical Release P0302. Pretoria, Statistics South Africa, 2011.

Umar, R. A.; Hassan, S. W.; Ladan, M. J.; Matazu, I. K.; Shehu, B.; Shehu, R. A.; Muhammed, L. G. \& Molabo, F. I. Adverse hepatic effects associated with administration of antiretroviral drugs (nevirapine, lamivudine and stavudine) to albino rats: Implication for management of patients with HIV/AIDS. Asian J. Biochem., 3(1):19-25, 2008.

Joint United Nations Programme on HIV/AIDS (UNAIDS). Report on the global AIDS epidemic and document library. Geneva, Joint United Nations Programme on HIV/AIDS (UNAIDS), 2009.
World Health Organization (WHO). Towards Universal Access. Scaling up priority HIV/AIDS interventions in the health sector. Progress Report, April 2007. Geneva, World Health Organization, UNAIDS, UNICEF, 2008.

Correspondence to:

Dr. Ajayi Sunday Adelaja

Discipline of Clinical Anatomy

School of Laboratory Medicine \& Medical Sciences

Nelson R Mandela School of Medicine

University of KwaZulu-Natal

Private Bag X54001, Congella 4013

Physical address: 719 Umbillo Road

Durban

SOUTH AFRICA

Tel. (office): +27 (0) 312604576

Tel. (mobile): +27 (0) 843946474

Email: Ajayis@ukzn.ac.za

Received: 21-05-2015

Accepted: 24-12-2015 